\title{
Induction of resistance in onion against purple leaf blotch disease through chemicals
}

\author{
Muhammad Younas ${ }^{1}$, Muhammad Atiq1 ${ }^{*}$, Nasir Ahmed Rajput ${ }^{1}$, Wasim Abbas ${ }^{2}$, Muhammad Rizwan Bashir ${ }^{2}$, \\ Salman Ahmad ${ }^{3}$, Muhammad Sami Ullah ${ }^{1}$, Waqas Ashraf Bhatti ${ }^{4}$, Nadia Liaqat ${ }^{1}$, Irfan Ahmad ${ }^{5}$ \\ ${ }^{1}$ Department of Plant Pathology, University of Agriculture, Faisalabad, Pakistan \\ ${ }^{2}$ Plant Pathology Section, PPRI, Ayyub Agricultural Research Institute, Faisalabad, Pakistan \\ ${ }^{3}$ Department of Plant Pathology, College of Agriculture, University of Sargodha, Sargodha, Pakistan \\ ${ }^{4}$ Department of Plant Pathology, The Islamia University of Bahawalpur, Bahawalpur, Pakistan \\ ${ }^{5}$ Department of Forestry and Wildlife, University of Agriculture, Faisalabad, Pakistan
}

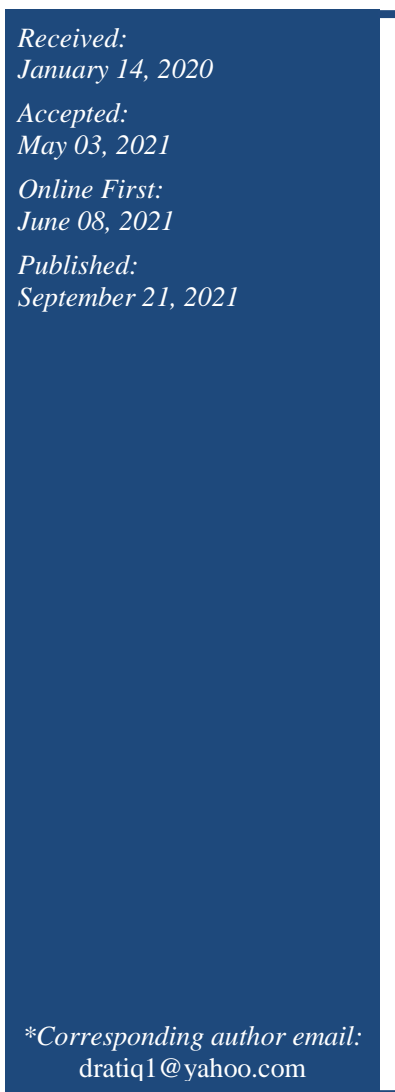

\begin{abstract}
Onion is one of the world's most important vegetable crop cultivated in Pakistan and plays a significant role in human diet. Numerous diseases attack on onion crop, but purple leaf blotch is the most important one, because it causes 80 to $90 \%$ of onion yield loss all over the world. In current experiment twenty-three fungicides at three concentrations $(0.5,1$, and $1.5 \mathrm{~g} / \mathrm{L})$ were evaluated against Alternaria porri causing purple blotch under Randomized Complete Block Design (RCBD) on susceptible variety of onion (Pink Panther). Among all fungicides, chlorostrobin expressed prominent results causing $62.05 \%$ reduction in disease severity, followed by Nanok (61.55), Shincar (54.86), Cabrio Top (53.33), Thril (50.00), Jalwa (48.11), Success (45.00), Alliette (41.61), Rally (39.83), Copper oxychloride (36.66), Score (33.05), Topas (29.88), Melodydue (13.27), Dithane M (11.66), Sulphax (6.55), Ridomil Gold (3.38) \% respectively as compared to control. Similar results were observed in case of interaction $\mathrm{b} / \mathrm{w}$ treatments and their concentrations. Results of current study are helpful for farmers, scientist, and researchers for timely management of purple leaf blotch disease of onion.
\end{abstract}

Keywords: Amaryllidaceae, Allium cepa, Chlorostrobin, Nanok, Fosetyl Aluminium

\section{How to cite this:}

Younas M, Atiq M, Rajput NA, Abbas W, Bashir MR, Ahmad S, Ullah MS, Bhatti WA, Liaqat N and Ahmad I, 2021. Induction of resistance in onion against purple leaf blotch disease through chemicals. Asian J. Agric. Biol. 2021(4): 202001039. DOI: https://doi.org/10.35495/ajab.2020.01.039

This is an Open Access article distributed under the terms of the Creative Commons Attribution 3.0 License. (https://creativecommons.org/licenses/by/3.0), which permits unrestricted use, distribution, and reproduction in any medium, provided the original work is properly cited.

\section{Introduction}

Onion (Allium cepa L.) is one of the most important bulb crop, among all vegetables (Teshika et al., 2019) that belongs to family Amaryllidaceae genus Allium (Akbar, 2020). The Mediterranean and South West Asia are the native regions for the growth of onion
(Ekşi et al., 2020). It is well known due to its pungent taste and presence of sulfenic acid. Onion plays a crucial role in different industries including food and medicine. It contains carbohydrates $(8.7 \mathrm{~g})$, soluble proteins $(9.22-13.21 \mathrm{~g})$, vitamin $\mathrm{C}(45.07 \mathrm{mg})$ and $88.65 \%$ water in 100gram sample of fresh onion (Sami et al., 2021), while onion contains natural beneficial 
compounds including thiosulfinates, saponins, polyphenols (Golubkina and Gianluca, 2020) and flavonoids (especially in red onion) (Akbar, 2020). 99.9 million tonns worldwide production was recorded from an area of 5.19 million hectares (FAO, 2019) while in Pakistan 2.06 million tonnes production was recorded from an area of 146.1 thousand hectares (GOP, 2020).

Onion crop is susceptible to attack by various fungal, bacterial, and viral diseases. Among them, purple blotch is most destructive and damaging foliar disease of onion which is caused by a fungal pathogen Alternaria porri (Firdausi et al., 2020). The attack of A. porri is more sever in humid and warm environment. Purple blotch occurs in severe form on seed crop as compared to bulb crop and causes 30-100 percent seed loss (Sonawane et al., 2020). Disease risk can be minimized by crop rotation, fungicides and biocontrol agents like Trichodema viridi, Trichodema virens, Trichodema harzianum and Penicillium citrinum which expressed inhibitory effect towards spore germination of A. porri (Hariprasad et al., 2021; Firdausi et al., 2020) but unfortunately these biocontrol agents are slow acting and suppress the pest population rather than killing them. That's why these are not adopted by farmers.

Different cultural and agronomic practices are used to minimize the risk of diseases but these put heavy labor cost and require extra time \& manpower. Use of plant extracts against purple blotch is another alternative method against this disease because plants are rich sources of bioactive compounds (Dar et al., 2020). Extracts of higher plants have insecticidal, antibacterial, and antifungal properties (Abdelkhalek et al., 2020; Ghasemi et al., 2020). Extracts of plants such as Azadirchta indica, Adhatoda vasica, Datura metal, Ocimum sanctum, Calotropis procera, Annona reticulata, Spilenthis acmela, and Lawsonia inermis are used against purple blotch disease (Islam et al., 2020; Rahman et al., 2015) but unfortunately plant extracts are not easily available and are slow action against diseases but can be control through the use of chemical fungicides (Islam et al., 2020) like Ridomil, mencozeb, hexaconazole, penconazole, difenoconazole, Azoxystobin (Paneru et al., 2020; Dar et al., 2020). Purple blotch can also be significantly reduced by following seed treatment with Vitavax Power@ of 5g/ Kg of seed along with foliar application of Tebuconazol 25 EC @ $1 \mathrm{ml}^{-1}$ (Mandi et al., 2020). Management of disease by using fungicides is mostly preferred because resistant sources are not always desirable and effective. Among all methods, response chemical method is very quick, and farmer is forced to use fungicides when disease appears in the field in epidemic form. Therefore, the current study was designed to evaluate different fungicides at different concentrations against purple blotch under field conditions.

\section{Material and Methods}

\section{Isolation, identification and purification of Alternaria porri}

Potato dextrose agar (PDA) media was prepared for the isolation of $A$. porri by using boiled potato slices, dextrose, and agar. Sterilized Petri plates $(100 \mathrm{~mm} \times 15 \mathrm{~mm})$ were used during experiment to avoid contamination. Onion infected leaves exhibiting characteristic symptoms of purple leaf blotch were collected and brought to Plant Pathology laboratory, Department of Plant Pathology, University of Agriculture, Faisalabad. Diseased portion of leaves along with some healthy portion were cut into small pieces $(2 \mathrm{~mm})$ and sterilized with $70 \%$ ethanol for 60 sec and placed on the Petri plates containing media and put them in an incubator (GEN2 BOD) at $21^{\circ} \mathrm{C}$ temperature under dark conditions and observed daily for fungal growth.

\section{Evaluation of fungicides under field conditions}

Present experiment was conducted in Vegetable Research Institute, AARI Faisalabad in 2019. Susceptible variety namely Pink Panther was collected from a Vegetable Research Institute, Ayyub Agricultural Research Institute (AARI), Faisalabad. Susceptible variety of onion was cultivated by following $(\mathrm{R} \times \mathrm{R})$ and $(\mathrm{P} \times \mathrm{P})$ distance of $30 \mathrm{~cm}$ and 10 $\mathrm{cm}$ respectively under Randomized Complete Block Design (RCBD) by following all horticultural and husbandry practices (weeding and hoeing etc.). Twenty three fungicides (Cabrio Top, Success 40 WSP, Antracol, Melody Due, Curzate M, Ridomil Gold, Rally, Alliette, Cytrol, Co Pride, Thrill, Shincar, Topas, Score, Tilt, Flu Max, Jalwa, Chlorostrobin, Nanok, Copper Oxychloride, Dithane M, Topsin M, Sulphax) were collected from market and were evaluated at three concentrations $(0.5 \mathrm{~g}, 1.5$ and $1.0 \mathrm{~g} / \mathrm{liter}$ of water). Hand sprayer (1 HT-401) was used for the application of fungicides on every row of varieties. First spray of fungicides was applied on the appearance of disease symptoms were appeared under natural conditions. While remaining two sprays were 
carried out at the interval of 10 days by hand sprayer. Disease data was recorded by following visual observations and rating scale (Sharma, 1986).

According to this scale:

\begin{tabular}{|l|c|c|}
\hline \multicolumn{1}{|c|}{ Description } & Rating Scale & Response \\
\hline $\begin{array}{l}\text { Disease symptoms are not } \\
\text { present }\end{array}$ & 0 & I \\
\hline $\begin{array}{l}\text { Few spots present on the tip, } \\
\text { covers less than 10\% leaf area }\end{array}$ & 1 & R \\
\hline $\begin{array}{l}\text { Dark purplish brown patches } \\
\text { are present covering less than } \\
\text { 20\% leaf area }\end{array}$ & 2 & MR \\
\hline $\begin{array}{l}\text { Patches along with paler outer } \\
\text { region, covering up to 40\% } \\
\text { leaf area }\end{array}$ & 3 & MS \\
\hline $\begin{array}{l}\text { long lines are present covering } \\
\text { up to 75\% leaf area }\end{array}$ & 4 & S \\
\hline $\begin{array}{l}\text { Complete leave dried or its } \\
\text { breakdown occur from stalk }\end{array}$ & 5 & HS \\
\hline
\end{tabular}

$\mathrm{I}=$ Immune, $\mathrm{R}=$ Resistant, MR= Moderately

Resistant, MS= Moderately Susceptible,

$\mathrm{S}=$ Susceptible, HS= Highly Susceptible

Data of disease severity was recorded by adapting following formula (Wheeler, 1969)

Disease severity $(\%)=\frac{\text { Sum of all individual disease rating }}{\text { Total No. of plant assessed } \times \text { Maximum rating }} \times 100$

While reduction in disease severity was calculated by using following formula after application of fungicides against purple leaf blotch of onion

Reduction in disease severity (DS) $\%=\frac{\text { DS in control plants }- \text { DS in treated plants }}{\text { DS in control plants }} \times 100$

\section{Statistical analysis}

Data was examined through analysis of variance (ANOVA) and treatments were compared by using Fisher's Least Significant Difference (LSD) test. All the statistical tests were performed by using SAS statistical software.

\section{Results}

\section{Identification of Alternaria porri on the basis microscopy}

Light to dark olivacious and grayish white colonies with concentric rings were appeared. Colony margins were complete, irregular, and wavy with fluffy and velvety texture while conidial shape was straight to curve along with light to deep brown colour which confirms the existence of $A$. porri. The number of horizontal and vertical separation in the conidia ranged from 3.00 to $6 \mu \mathrm{mm}$ as shown in fig.

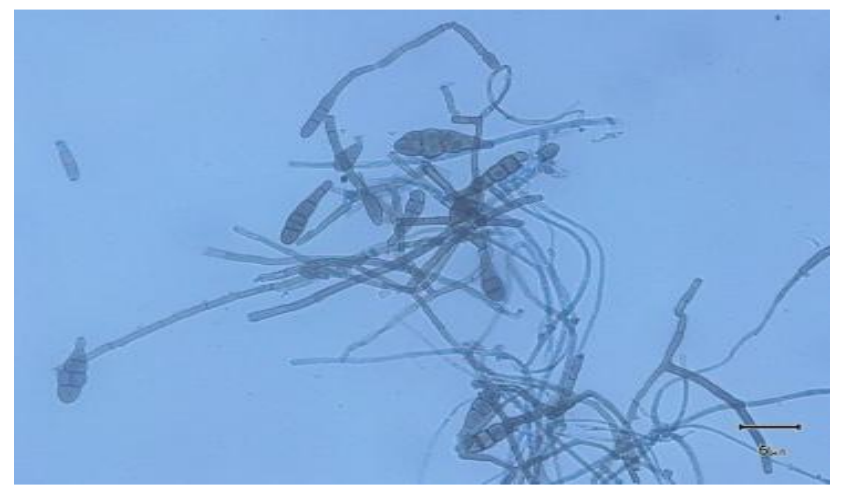

Figure-1. Microscopic view of Alteria porri causing purple blotch of onion.

\section{Evaluation of chemicals against purple blotch disease under field conditions}

Pink panther exhibits susceptible response with $70 \%$ severity of purple blotch disease, So this variety was used for determining the efficacy of fungicides towards A.porri; Among all treatments, Chlorostrobin expressed (62.05)\% reduction in disease severity followed by Nanok (61.55\%), Shincar (54.86\%), Cabrio Top (53.33\%), Thrill (50.00\%), Topsin M (49.83\%), Jalwa (48.11\%), Cytrol (45.00\%), Copride (45\%), Success 40 WSP (45\%), Tilt (44.66\%), Alliette (41.61\%), Flu max (41.55\%), Rally(39.83\%), Copper oxychloride (36.66\%),Score (33.05\%), Antracol (30.\%), Topas (29.88\%), Melody due (13.27\%), Dithane M (11.66\%), Curzate $(6.66 \%)$, Sulphax $(6.55 \%)$ and Ridomil gold $(3.38 \%)$ respectively as compared to control as shown in table1 and fig. 2

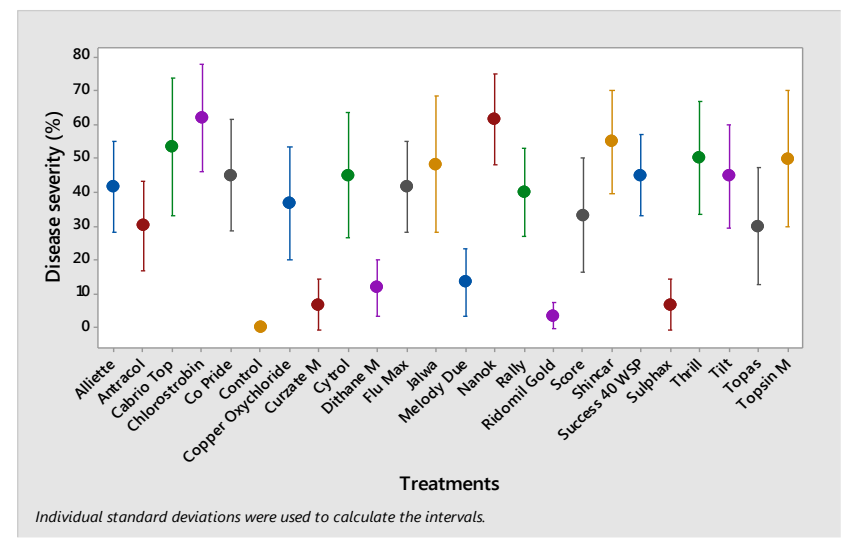

Figure-2. Evaluation of different fungicides against purple blotch disease under field conditions 
Table-1. Reduction in severity of purple leaf blotch of onion under field conditions

\begin{tabular}{|c|c|c|c|}
\hline Sr.\# & Treatments & Active ingredients & $\begin{array}{c}\text { Reduction in } \\
\text { Disease Severity } \\
(\%)\end{array}$ \\
\hline 1 & Cabrio Top & Pyraclostrobin & $53.33 \mathrm{c}$ \\
\hline 2 & Success 40 WSP & Chlorothalonil +Metalaxyl & $45.00 \mathrm{f}$ \\
\hline 3 & Antracol & Propineb & $30.00 \mathrm{k}$ \\
\hline 4 & Melody Due & Iprovalicarb +Propineb & 13.271 \\
\hline 5 & Curzate M & cymoxanil + mancozeb & $6.66 \mathrm{n}$ \\
\hline 6 & Ridomil Gold & Metalaxyl + Mancozeb & $3.38 \mathrm{o}$ \\
\hline 7 & Rally & Myclobutanil & $39.83 \mathrm{~h}$ \\
\hline 8 & Aliette & Fosetyl Aluminium & $41.61 \mathrm{~g}$ \\
\hline 9 & Cytrol & Thiophanate & $45.00 \mathrm{f}$ \\
\hline 10 & Co Pride & Copper Oxychloride & $45.00 \mathrm{f}$ \\
\hline 11 & Thrill & Bismenthazole & $50.00 \mathrm{~d}$ \\
\hline 12 & Shincar & Carbendazim & $54.86 \mathrm{~b}$ \\
\hline 13 & Topas & Penconazole & $29.88 \mathrm{k}$ \\
\hline 14 & Score & Diafinaconazole & $33.05 \mathrm{j}$ \\
\hline 15 & Tilt & Propiconazole & $44.66 \mathrm{f}$ \\
\hline 16 & Flu Max & Metalaxyl-m+fluazinam & $41.55 \mathrm{~g}$ \\
\hline 17 & Jalva & Deltamethrine +Triazophos & $48.11 \mathrm{e}$ \\
\hline 18 & Chlorostrobin & Azoxystrobin+chlorothalonil & $62.05 \mathrm{a}$ \\
\hline 19 & Nanok & Flutrifol + Azoxystrobin & $61.55 \mathrm{a}$ \\
\hline 20 & Copper & Copper & $36.66 \mathrm{i}$ \\
\hline 21 & Dithane M & Mancozeb & $11.66 \mathrm{~m}$ \\
\hline 22 & Topsin M & Thiophanate methyl & $49.83 \mathrm{~d}$ \\
\hline 23 & Sulphax & Sulphur & $6.55 \mathrm{n}$ \\
\hline 24 & Control & Distilled water & $0.00 \mathrm{p}$ \\
\hline
\end{tabular}

* Mean values in a column sharing similar letters do not differ significantly as determined by the LSD test $(\mathrm{P} \leq 0.05)$.

Impact of interaction between treatments and concentrations on the development of onion purple leaf blotch under field conditions

In case of interaction between treatments and their concentrations on the development of purple blotch disease of onion under field conditions, Chlorostrobin expressed maximum disease reduction $(39.50,60$, $86.66 \%$ ) @ of $0.5,1,1.5 \mathrm{~g} / \mathrm{L}$ of water, followed by Nanok (40, 65, 79.66\%), Shincar (35.00, 49.66, $79.91 \%$ ) Cabrio Top (20, 60, 80\%), Cytrol (20.00, $40.00,75.00 \%)$, Thrill $(25,50,75 \%)$, Copride $(20,45$, $70 \%)$, Success 40 WSP $(25,50 ., 60 \%)$, Rally $(20,40$ $, 59.50 \%)$, Alliette $(20,44.83,60 \%)$, Flu Max (20,44.66, 60\%), Topsin M (19.66, 49.83, 80\%), Jalwa $(19.66,44.66,80 \%)$, copperoxy chloride $(10,40,60 \%)$ Antracol (10.33, 29.66, 50\%), Score (9.66, 29.50, $60 \%)$ Topas $(10,20,59.66 \%)$, Melody due $(0.00,10$, $29.83 \%)$, Dithane $\mathrm{M}(0.00,10,25 \%)$, Curzate $\mathrm{M}(0.00$, $0.00,20 \%)$, Sulphax $(0.00,0.00,19.66 \%)$ Ridomil gold $(0.00,0.00,10.16 \%)$ at all concentrations i.e. 0.5 , 1 and $1.5 \mathrm{~g} / \mathrm{L}$ of water respectively as shown in table 2 and fig. 3 .
Table-2. Effect of interaction between treatments and concentration on the development of purple blotch disease under field conditions

\begin{tabular}{|l|c|c|c|}
\hline \multirow{2}{*}{ Treatments } & \multicolumn{3}{|c|}{ Reduction in disease severity (\%) } \\
\cline { 2 - 4 } & $\begin{array}{l}\text { 0.5g/liter of } \\
\text { water }\end{array}$ & $\begin{array}{l}\text { 1.0g/liter of } \\
\text { water }\end{array}$ & $\begin{array}{l}\text { 1.5g/liter of } \\
\text { water }\end{array}$ \\
\hline Cabrio Top & $20.00 \mathrm{~m}$ & $60.00 \mathrm{f}$ & $80.00 \mathrm{~b}$ \\
\hline Success 40 WSP & 25.001 & $50.00 \mathrm{~g}$ & $60.00 \mathrm{f}$ \\
\hline Antracol & $10.33 \mathrm{n}$ & $29.66 \mathrm{k}$ & $50.00 \mathrm{~g}$ \\
\hline Melody Due & $0.00 \mathrm{o}$ & $10.00 \mathrm{n}$ & $29.83 \mathrm{k}$ \\
\hline Curzate M & $0.00 \mathrm{o}$ & $0.00 \mathrm{o}$ & $20.00 \mathrm{~m}$ \\
\hline Ridomil Gold & $0.00 \mathrm{o}$ & $0.00 \mathrm{o}$ & $10.16 \mathrm{n}$ \\
\hline Rally & $20.00 \mathrm{~m}$ & $40.00 \mathrm{i}$ & $59.50 \mathrm{f}$ \\
\hline Alliette & $20.00 \mathrm{~m}$ & $44.83 \mathrm{~h}$ & $60.00 \mathrm{f}$ \\
\hline Cytrol & $20.00 \mathrm{~m}$ & $40.00 \mathrm{i}$ & $75.00 \mathrm{c}$ \\
\hline Co Pride & $20.00 \mathrm{~m}$ & $45.00 \mathrm{~h}$ & $70.00 \mathrm{~d}$ \\
\hline Thrill & 25.001 & $50.00 \mathrm{~g}$ & $75.00 \mathrm{c}$ \\
\hline Shincar & $35.00 \mathrm{j}$ & $49.66 \mathrm{~g}$ & $79.91 \mathrm{~b}$ \\
\hline Topas & $10.00 \mathrm{n}$ & $20.00 \mathrm{~m}$ & $59.66 \mathrm{f}$ \\
\hline Score & $9.66 \mathrm{n}$ & $29.50 \mathrm{k}$ & $60.00 \mathrm{f}$ \\
\hline Tilt & 24.501 & $40.00 \mathrm{i}$ & $69.50 \mathrm{~d}$ \\
\hline Flu Max & $20.00 \mathrm{~m}$ & $44.66 \mathrm{~h}$ & $60.00 \mathrm{f}$ \\
\hline Jalwa & $19.66 \mathrm{~m}$ & $44.66 \mathrm{~h}$ & $80.00 \mathrm{~b}$ \\
\hline Chlorostrobin & $39.50 \mathrm{i}$ & $60.00 \mathrm{f}$ & $86.66 \mathrm{a}$ \\
\hline Nanok & $40.00 \mathrm{i}$ & $65.00 \mathrm{e}$ & $79.66 \mathrm{~b}$ \\
\hline $\begin{array}{l}\text { Copper } \\
\text { oxychloride }\end{array}$ & $10.00 \mathrm{n}$ & $40.00 \mathrm{i}$ & $60.00 \mathrm{f}$ \\
\hline Dithane- M & $0.00 \mathrm{o}$ & $10.00 \mathrm{n}$ & 25.001 \\
\hline Topsin- M & $19.66 \mathrm{~m}$ & $49.83 \mathrm{~g}$ & $80.00 \mathrm{~b}$ \\
\hline Sulphax & $0.00 \mathrm{o}$ & $0.00 \mathrm{o}$ & $19.66 \mathrm{~m}$ \\
\hline Control & $0.00 \mathrm{o}$ & $0.00 \mathrm{o}$ & $0.00 \mathrm{o}$ \\
\hline
\end{tabular}

*Mean values in a column sharing similar letters do not differ significantly as determined by the LSD test $(\mathrm{P} \leq 0.05)$.

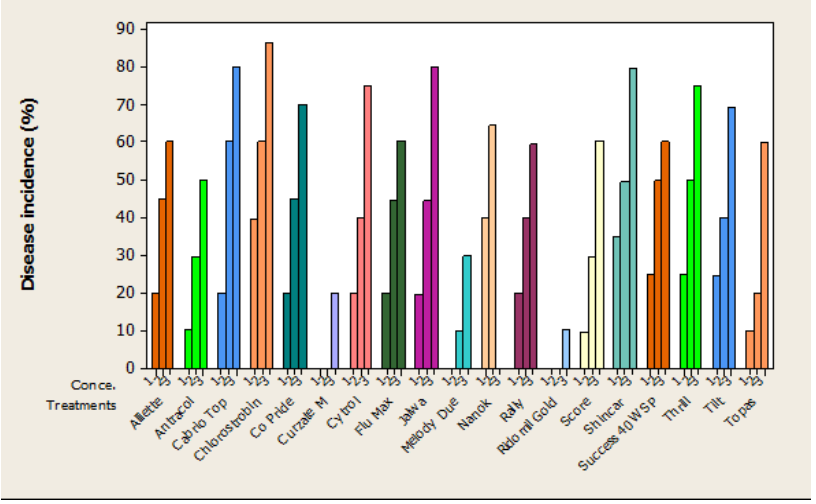

Figure-3. Assessment of interaction between treatments and concentrations against purple leaf blotch under field conditions 


\section{Discussion}

Onion purple leaf blotch is the most disparaging disease caused by Alternaria porri. Among fungal diseases (Bal et al., 2019) which causes 50\% yield losses (Jhala et al., 2017). Development of disease depends on the time of infection and host genotype. A. porri attacks on aerial plants parts. Presence of favorable environmental conditions (temperature, relative humidity, rainfall, and wind speed) susceptible germplasm and virulence strain of pathogen are responsible for the disease development. Most economical way for the management of purple blotch is the use of resistant varieties, but due to scarcity of resistant varieties, if the disease appeared in the field in epidemic form, then farmers have only one option, which is the use of chemical fungicides towards purple blotch of onion, as it is quick in action and easily available. Therefore, current study was designed for evaluation of different chemical fungicides against purple leaf blotch of onion under field conditions. So in in current study, twenty-three fungicides were evaluated against purple blotch of onion under field conditions at three concentrations. Among these fungicides, chlorostrobin (azoxystrobin + chlorothalonil) was proved most effective by causing $62.05 \%$ reduction in disease severity followed by Nanok (azoxystrobin+ Flutriafol), Shincar (carbendazim), Cabrio Top (Metiram + Pyraclostrobin), Thrill (Bismirthazole), which expressed up to $50 \%$ reduction and nine fungicides namely Jalwa (Penthiopyrad), Success40 WSP (Chlorothalonil + Metalaxyl), Cytrol, Copride, Alliette (Fosetyl Aluminium), Flu Max, Tilt, Rally (Myclobutanil) and Topsin M causes up to $40 \%$ reduction in disease while four fungicides Copper oxychloride (Copper) and Score (Difenaconazole), Topas (Penaconazole + Difenaconazole), Antracol, controlled more than $30 \%$ disease and remaining five fungicides Melody due (Propineb + iprovalicarb), Dithane M (Dithiocarbamates), Curzate M, Sulphax (sulphur) and Ridomil gold (Mancozeb + Metalaxyl) controlled less than $20 \%$ disease respectively as compared to control.

Paneru et al. (2020) worked on different six chemical fungicides for determining their efficacy against purple leaf blotch disease and found that Mencozeb + Cymoxanil expressed maximum reduction in disease severity followed by hexaconazole, Tebuconazole, Dimethomorph and carbendazim. Similarly, Mandi et al. (2020) used combinations of different fungicides along with seed treatment of vitavax power against purple bloch disease of onion. It was concluded that foliar application of Tubaconazole $25 \mathrm{EC} @ 1 \mathrm{ml}^{-1}$ and Azoxystrobin $23 \mathrm{SC} @ 1 \mathrm{ml}^{-1}$ was the most effective in controlling disease followed by Difenoconazole 25 EC @ $0.6 \mathrm{ml} \mathrm{1}^{-1}$. In contemporary studies, chlorostrobin expressed significant results by suppressing $A$. porri because it consists of azoxystrobin and chlorothalonil which inhibits multi sites of different enzymes. Nanok is effective fungicide against various diseases belonging to Ascomycetes, Basidiomycetes, Deuteromycetes, and oomycetes as, it has curative as well as protectant properties and is highly systemic which results in long term efficacy It inhibits the respiration, mycelial growth, spore germination and maintains normal green leaf area which results into high average potential yield. Cabrio Top caused reduction in disease severity up to $50 \%$ by blocking energy supply to fungus. Alliette causes $40 \%$ disease reduction due to its systemic nature as well as multiple modes of action as, it attacks on various growth stages of pathogens which results into rapidly disease reduction, Alliette not only controlled the plant pathogen but also stimulates the defense system of plant by creating a barrier in plant against pathogens and inhibited fungal spore germination by preventing disease transmission. Score causes more than $30 \%$ reduction in disease severity by suppressing the biosynthesis of sterol in cell membrane.

Results of the present study are also supported by the work of Ali et al. (2016), who concluded that chemical fungicides showed best results by reducing and inhibiting fungal mycelial growth. Results of Ekabote (2020) and Ravikumar et al. (2020) are hand in line with the results of present experiment who determined that Tubeconazole and Trifloxystrobin (chlorostrobin) is best fungicide for the management of $A$. porri. They described that isolates are more sensitive to chlorothalonil as compared to mancozeb against purple blotch disease. Results of the contemporary study are helpful for the management of purple leaf blotch for farmers and researchers and scientists.

\section{Conclusion}

Chlorostrobin and Nanok expressed maximum reduction in disease severity under field conditions at the rate of $1.5 \mathrm{~g} / \mathrm{L}$. So, it is recommended for farmers to use these fungicides should be used by farmers and researchers against purple leaf blotch of onion. 


\section{Acknowledgement}

The authors are grateful to the Ayub Agricultural Research Institute (AARI) Faisalabad to allow carrying out field trials in experimental area of plant pathology section. The authors are highly thankful o Phytopathology Laboratory, University of Agriculture, Faisalabad.

\section{Human and animal rights}

This research does not include any animal and/or human trials.

\section{Disclaimer: None.}

Conflict of Interest: None.

Source of Funding: None.

\section{References}

Abdelkhalek A, Salem MZ, Kordy AM, Salem AZ and Behiry SI, 2020. Antiviral, antifungal, and insecticidal activities of Eucalyptus bark extract: HPLC analysis of polyphenolic compounds. Microb. Pathogen. 147: 104383.

Akbar S, 2020. "Allium cepa L. (Amaryllidaceae)." Handbook of 200 Medicinal Plants. Springer, Cham. 139-160.

Ali HH, Nisha AC, Hossain MB and Islam MR, 2016. Evaluation of Combined Effect of Micronutrients (ZnSO4+ Borax) and Fungicides to Control the Purple Blotch Complex of Onion (Allium cepa). Am. J. Plant Sci. 7: 715.

Bal S, Maity TK, Sharangi AB and Maji A, 2019. Screening of onion (Allium cepa L.) germplasm against purple blotch disease. J. Pharmacogn. Phytochem, 8(6): 546-548.

Dar AA, Sharma S, Mahajan R, Mushtaq M, Salathia A, Ahamad S and Sharma JP, 2020. Overview of purple blotch disease and understanding its management through chemical, biological and genetic approaches. J. Integr. Agric. 19(12): 30133024.

Ekabote SD, 2020. Bio-Efficacy and Phytotoxicity of Tebuconazole 430 SC on Onion Purple Blotch under Field Condition. Chem. Sci. Rev. Lett. 9(35): 646-650.

Ekşi G, Gençler Özkan AM and Koyuncu M, 2020. Garlic and onions: An eastern tale. J. Ethnopharmacol. 253:112675. DOI: 10.1016/j.jep.2020.112675.

FAO STAT, 2019-20. Food and Agriculture Organization of the United Nations, Rome, Italy.

Firdausi W, Sulistyowati L and Aini LQ, 2020. Exploration and Antifungal Assay of Endophytic Fungi as Biocontrol of Onion Purple Blotch Disease Caused by Alternaria Porri (Ell) Cif in vitro. AGRIVITA, J. Agric. Sci. 43(1). DOI: http://doi.org/10.17503/agrivita.v43i1.2838.

Ghasemi G, Alirezalu A, Ghosta Y, Jarrahi A, Safavi SA, Abbas-Mohammadi M, Barba FJ, Munekata PE, Domínguez R and Lorenzo JM, 2020. Composition, antifungal, phytotoxic, and insecticidal activities of thymus kotschyanus essential oil. Molecules. 25(5): 1152.

Golubkina N and Gianluca C, 2020. Onion. Nutritional Composition and Antioxidant Properties of Fruits and Vegetables. Academic Press, pp. 73-87.

GOP, 2020. Economic survey of Pakistan 2019-20. Govt. of Pakistan, Islamabad, Pakistan.

Hariprasad K, Palakshappa MG, Dinesh K and Iliger KS, 2021. Efficacy of bio control agents under in vitro against Alternaria porri (Ellis) Cifferi. Causing purple blotch in onion. The Pharma Innov. Int. J. 10(4): 81-84. DOI: https://doi.org/10.22271/tpi.2021.v10.i4b.5925.

Islam $M$, Begum $F$, Nahar $N$, Habiba $U$ and Fakruzzaman K, 2020. In-Vivo Management of Purple Blotch of Onion Caused by Alternaria porri (Ellis) Cif. through Fungicides. Am. J. Plant Sci.11: $1847-1859$. DOI: 10.4236/ajps.2020.1111132.

Islam $M$, Begum $F$, Nahar $N$, Habiba $U$ and Fakruzzaman K, 2020. In vivo and In vitro Management of Purple Blotch of Onion by Using Fungicides and Plant Extracts. Int. J. Sci. Res. 9(10): 930-938. DOI:10.21275/SR201008003034.

Jhala P, Meena MK and Mali BL, 2017. Impact of abiotic factors and age of host plant on purple blotch of onion caused by Alternaria porri (Ellis) and estimation of yield losses. J. Plant Develop. Sci. 9(5): 447-451.

Mandi N, Nayak BS, Sahoo BB, Prasad G and Khanda C, 2020. Efficacy of Novel Fungicides against Purple Blotch in Onion (Allium cepa L.) in the Western Undulating Zone of Odisha, India. Int. J. Curr. Microbiol. App. Sci. 9(4): 1970-1976.

Paneru N, Adhikari P and Tandan P, 2020. Management of Purple Blotch Complex of Onion (Allium cepa $\mathrm{Cv}$ Red Creole) Under Field 
Condition In Rukum-West, Nepal. Malay. J. Sust. Agric. (MJSA). 4(2): 71-74. DOI: 10.26480/mjsa.02.2020.71.74

Rahman SM, Maniruzzaman SM, Nusrat S and Khair A, 2015. In vitro evaluation of botanical extract, bioagents and fungicides against purple blotch diseases of bunch onion in Bangladesh. Adv. Zool. Bot. 3: 179-183.

Ravikumar MR, Harish DK, Kumara BH and Kumar A, 2020. Evaluation of Pre-mix Fungicide, Fluopyram and Trifloxystrobin 250SC against Purple Blotch Disease of Onion in Karnataka. Curr. J. Appl. Sci. Technol. 39(8): 4450. DOI:10.9734/cjast/2020/v39i830591.

Sami R, Elhakem A, Alharbi M, Benajiba N, Almatrafi $M$ and Helal M, 2021. Nutritional Values of Onion Bulbs with Some Essential Structural Parameters for Packaging Process. Appl. Sci. 11(5): 2317.

Sharma S, 1986. Effect of fungicidal sprays on purple blotch and bulb yield of onion. Indian Phytopathol. 39: 78-82.

Sonawane RB, Dhemre JK, Badgujar MP and Gaikwad SD, 2020. Survey of Purple Blotch of Onion (Alternaria porri) in major Onion Growing Area in Nashik, India. Int. J. Curr. Microbiol. App.
Sci. 9(1): 1549-1554.

Teshika JD, Zakariyyah AM, Zaynab T, Zengin G, Rengasamy KR, Pandian SK and Fawzi MM, 2019. Traditional and modern uses of onion bulb (Allium cepa L.): a systematic review. Crit. Rev. Food Sc. Nutr. 59: S39-S70.

Wheeler BEJ, 1969. An introduction to plant diseases. John Willey and Sons Ltd. London, UK. p. 301.

\section{Contribution of Authors}

Younas M: Data collection and manuscript writing

Atiq M: Conceived idea, data analysis and literature review

Rajput NA, Liaqat N \& Ahmad I: Data analysis and interpretation

Abbas W \& Bhatti WA: Manuscript writing and approval

Bashir MR: Designed research methodology and collected data

Ahmad S \& Ullah MS: Literature review and manuscript write up 